\title{
Reactions to Social Quotas: a study of Facebook comments in Brazilian Portuguese
}

\author{
Rodrigo Esteves de LIMA-LOPES 『 \\ Universidade Estadual de Campinas (UNICAMP)
}

\section{ఠ \\ OPEN ACCESS \\ EDITED BY \\ - Andre Vinicius Lopes Coneglian (UFMG) \\ - Maria Helena de Moura Neves (UNESP) \\ - Lachlan Mackenzie (VUA) \\ REVIEWED BY \\ - Renata Condi (FMU) \\ - Juliano Antonio (UEM) \\ DATES \\ - Received: 05/10/2020 \\ - Accepted: 11/11/2020 \\ - Published: 17/12/2020 \\ HOW TO CITE \\ Lima-Lopes, R. E. (2020). Reactions to Social Quotas: a study of Facebook comments in Brazilian Portuguese. Revista da Abralin, v. 19, n. 3, p. 211-239, 2020.}

\section{ABSTRACT}

This paper aims to discuss how Facebook users reacted to the news that the Federal University of Bahia (Brazil) introduced social quotas for socially vulnerable transsexuals, immigrants and refugees. It tries to understand how lexicogrammatical choices might represent the various social entities which are present in users' comments. Data was automatically scraped from Facebook using Netvizz, and "R" scripts were written to process and analyse linguistic features. Results show that most of the comments are related to the interactions amongst users during the process of taking a stand in favour and against the system of quotas. There are also comments related to prejudice against northeast citizens and states. Grammatical patterns could be identified for each of those general themes present in the comments.

\section{RESUMO}

Este artigo tem como objetivo discutir como os usuários do Facebook reagiram às notícias de que a Universidade Federal da Bahia (Brasil) introduziu cotas sociais para transexuais, imigrantes e refugiados socialmente vulneráveis. Este trabalho tenta entender como as escolhas lexicogramaticais podem representar as várias entidades sociais presentes nos comentários dos usuários. A metodologia incluiu a raspagem automática de dados do Facebook, usando o software Netvizz. O processamento e a análise de dados empregavam o software "R", uma linguagem de programação de análise estatística computacional que permite, além de outras funções, extrair e analisar dados textuais. Os resultados mostram que a maioria dos 


\section{REVISTA DA ABRALIN}

comentários dos usuários está relacionada às interações entre os usuários durante o processo de tomada de posição a favor ou contra o sistema de cotas. Também existem comentários relacionados ao preconceito contra cidadãos e estados do nordeste. Padrões gramaticais podem ser identificados para cada um desses temas gerais presentes nos comentários.

\section{KEYWORDS}

Systemic-Functional Linguistics. Transsexuals. Refugees. Corpus Linguistics. Appraisal.

\section{PALAVRAS-CHAVE}

Linguística Sistêmico-Funcional. Transexuais. Refugiados. Linguística do Corpus. Avaliatividade.

\section{Introduction}

This article aims to analyse the lexicogrammatical patterns in a set comments made by users of a social media in Brazilian Portuguese (BP). The comments were a response to a Facebook post publicising that Federal University of Bahia (UFBA) had instituted a specific system of quotas for socially vulnerable transsexuals, transvestites, ${ }^{1}$ immigrants and refugees. The responsible for the post was "Quebrando o Tabu", ${ }^{2}$ a Brazilian internet news media. "Quebrando o Tabu" replicated a piece of hard news from a news website (Bahia Notícias), ${ }^{3}$ and it praised UFBA's announcement. Such an announcement had an important impact in the present political context in Brazil, since it took place a couple of weeks after a far-right candidate was elected for the Brazilian presidency.

This paper has its theoretical basis on the Systemic-Functional Linguistics (hereafter SFL) and Corpus Linguistics (hereafter CL). The main focus is to establish the transitivity and appraisal patterns that represent the social actors (VAN LEEUWEN, 2005) in such comments. This relationship between CL and SFL is possible on account of some common aspects both share as neo-Firthian approaches to language study (HASAN, 2014; STUBBS, 1996). Firstly, CL and SFL rely on empirical

\footnotetext{
${ }^{1}$ In this paper, the use of the words transvestite and transsexual is aligned with some cultural practices in the Brazilian context. Although such terms might seem offensive in some cultures, they are common use in Brazilian Portuguese, mostly because they have reflected a search for identity and visibility of some members of the LGBTQi+ community.

${ }^{2}$ https://www.facebook.com/quebrandootabu/

${ }^{3}$ https://bit.ly/2ZuHCmb
} 


\section{REVISTA DA ABRALIN}

data analysis as their main source of linguistic insight, as they investigate instantiation patterns within the various linguistic and social contexts based on real-occurring language data (BEAUGRANDE, 2002; BIBER; CONRAD; REPPEN, 1998). CL and SFL see form and meaning as indissociable, recognising that meaning is motivated by the relationship between the different lexicogrammatical elements in the different contexts of situation (HALLIDAY, 2003; HASAN, 2014; KRESS, 1993; MARTIN, 2016). For both, language is a social construct and an integral part of how we represent the world and our experiences (HALLIDAY, 2003). Consequently, language changes as the world changes, as also so do our choices at the lexicogramatical level. Therefore, mapping our language choices is an important part of understanding how different social groups are represented in different contexts of interaction.

The relevance of this study lies in the protagonism that social media have gained in our society. They are no longer just seen as the expression of youth culture (ELLISON; BOYD, 2013), being recognized for their importance as a political platform (MERCURI; LIMA-LOPES, 2020; RODRIGUES; FERREIRA, 2020; VISCARDI, 2020). They have had a decisive influence on contemporary elections (ALMEIDA, 2018; SILVA, 2018; VARIS, 2020) and a pivotal part in the dissemination of hate speech (BEN-DAVID; MATAMOROS-FERNANDEZ, 2016; LIMA-LOPES, 2018; OTTONI et al., 2018). Social media have also played an important role in processes of disinformation and misinformation (LAZER et al., 2018; PORCELLO; DIAS, 2018) and their consequences in everyday life, such as virtual lynching (MACEDO, 2018). Online social media, such as Facebook and Twitter, have aided the flourishing of several social movements, such as women's rights (GABARDO; LIMA-LOPES, 2018; LIMA-LOPES; GABARDO, 2019; LIMA-LOPES; PIMENTA, 2017) and mobilisation against censorship (LIMA-LOPES, 2019). Besides they have also been of paramount relevance to the LGBTQi+ community, as they offer a space for the construction of new identities that go beyond social conventions (BANKS, 2018; LIMALOPES; CÂMARA, 2019).

Data analysis was based on both qualitative and quantitative approaches. Data collection was performed by a social media scraping software, responsible for collecting all comments, as well as their reactions. A corpus clusterisation was calculated as a way of recognizing its main aboutness. Then, the comments were classified according to their position in relation to the UFBA's quota system and the meanings they instantiate. The functions and patterns of the most relevant clusters and lexical items were analysed using scripts for concordance. The analysis was based on a series of scripts written in $\mathrm{R}$ programming language written specially for this research. These scripts are available at the author's website and Git Hub repositories. ${ }^{4}$

Results showed that the discussions moved beyond the simple expression of opinions for or against the quota system. Racial and geographical prejudice (against Brazil north-eastern citizens) and intense interaction, not always friendly, amongst commenters were common. In the case of the latter, there is the presence of polarized political discussions and personal offences that are often

\footnotetext{
${ }^{4}$ All scripts will be available at: http://www.iel.unicamp.br/rll307 or https://github.com/rll307
} 


\section{REVISTA DA ABRALIN}

not even related to the main topic of the post. Finally, systems of choices regarding the evaluation and transitivity representations were drawn based on the meanings observed in the comments.

In order to fulfil the research objective, the next section presents the literature review, followed by the methods. The analysis of the data and the final remarks close this article.

\section{Literature review}

SFL is an approach that renders meaning and structure in order to describe how wordings are instantiated through paradigmatic system of socially motivated choices (HALLIDAY, 1994, 2004). The way the linguistic constituents are organised results from a deep relationship between the context and the communicational functions people perform (KRESS, 1993). According to Hasan (2014), Martin (2016) and Thompson (1996), language would be a probabilistic system of choices (HALLIDAY, 2005), which is conditioned by the context in which the speaker is. SFL takes all elements of text and context into account: form and meaning are equally important within a system that understands them as inseparable (HALLIDAY, 1994, p. 15), as any choice at the structural level reflects at the semantic and expression levels and vice versa.

For Martin and Rose (2003), social activity, discourse and grammar are phenomena operating at a different level abstraction. Such an interface becomes possible because cultures manifest themselves through texts constituted by smaller units such as sentences, periods and words. The instantiation process would be the translation of our social meanings into grammatical structures build into texts, allowing more abstract levels to become tangible language-level choices. Therefore, symbolizing is an essential and indispensable aspect; grammar would codify speech as it would instantiate social activity as texts (MARTIN; ROSE, 2003). So, a text is result of choices that occur at different levels (or strata), each responsible for some aspects of meaning and its translation into a language system. Consequently, each time meaning is instantiated, it represents a set of non-arbitrary and motivated choices (HALLIDAY, 2003; KRESS, 1993).

In SFL tradition, there are two levels of context: situation and culture. The context of culture can be understood as the background in which the interaction is, as it provides the social potential for realisation of meanings. The context of situation (or register) is related to the immediate situation of text realisation (HALLIDAY; HASAN, 1991) and it should be configured according to:

- Field or what the text is about;

- Tenor or the social structure, their hierarchical relationships and of solidarity;

- Mode or the role of language and its organization. 


\section{REVISTA DA ABRALIN}

The register variables are instantiated through three Language Metafunctions. Given the semantic-functional nature of communication, choices are not only structural, but they also reflect the ideological context a speaker is in. According to Halliday (1994), such metafunctions would be:

- Interpersonal: encompasses attitudes towards others and our social roles.

- $\quad$ Textual: organizes the text and gives it its status as a message.

- Ideational: refers to the representation of our experience.

Ideational metafunction could be defined as the grammatical resource by which language reaches its representational potential (HALLIDAY, 1994, 2004; THOMPSON, 1996). Such potential is instantiated by choices through the System of Transitivity, a system responsible for the expression of what Halliday and Matthiessen (2014) call a quantum of change. As one represents the world through language, she or he would actually be modelling this quantum into something similar to images of 'doing', 'happening', 'feeling', 'existing', 'saying' or 'being', images which depict the relationship amongst the entities present in the world. Hence, the system of transitivity provides the resources needed to transform this quantum of change into event streams through process choices and their arguments. Each process unfolds over time and establishes relationships with participants, who play roles in the proposition, and circumstantial elements, whose primary function would be to represent the background of such processes.

According to Halliday (1994), our meanings are expressed by means of six processes types: 1) material, which represents actions performed in the physical world; 2) mental, which represents our inner world; 3) relational, which brings meanings related to identification, possession and attribution; 4) behavioural, which is between the material and the mental, performing actions of our inner world that are externalized in material actions; 5) verbal, which is between the relational and mental, instating meanings of saying; and 6) existential, which are between the material and the relational, instantiating phenomena recognised as existing.

The analysis of appraisal is a further development of SFL, and it is a response to our constant feeling that our language choices are evaluating other people, our context as well as characterising our ideological stand (ALBA-JUEZ; THOMPSON, 2014; HUNSTON; THOMPSON, 2000). In order words, the system of appraisal is concerned with how users express their subjective stances in language, how speakers/writers approve/disprove the world they represent and the people they communicate to (MARTIN; WHITE, 2005). The analytical approach Martin and White (2005) propose concerns three subsystems according to the kind of evaluation they express. The first is attitude, responsible for mapping feelings as they are built into text. The attitude is divided into three subsystems (1) Affection, expressing positive and negative feelings, (2) Judgment, focusing on attitudes 


\section{REVISTA DA ABRALIN}

towards behaviours, which we may praise, criticise or condemn, and (3) Appreciation, representing aesthetic ideas.

The second is the system of engagement, and it makes possible for the writer/speaker to enlist (or not) him/herself interactively within the text. As any text would be the result of interaction with various other texts and voices, this system would be responsible for the systematic processes of performing commitment or non-commitment linguistically (MARTIN; WHITE, 2005, p. 93). Graduation, finally, can be defined as a form of intensification or mitigation of the meanings instantiated by the two other subsystems, which instantiate meanings regarding 1) Force - amount or intensity -, and 2) Focus - prototyping and accuracy. Focus can be described in terms of taxonomies which define the specificity of participation, while force instantiates meanings that would be quantified or intensified.

This article focuses on the system of attitude and its relationship with transitivity choices. Although the simultaneous analysis of these two systems is not the most orthodox analytical practice in SFL, several papers have shown its potential for identifying the ideological and discursive patterns in Brazilian Portuguese (LIMA-LOPES, 2018; LIMA-LOPES; GABARDO, 2019; LIMA-LOPES; PIMENTA, 2017; MERCURI; LIMA-LOPES, 2020).

\section{Methods}

Collocation could be defined as units of formulaic language choices which might be considered prominent in language use (GABLASOVA; BREZINA; MCENERY, 2017). Corpus analysis plays an essential role in understanding how lexical elements might combine to become identifiable as units of meaning. Of particular relevance to the approach in this paper is the idea that a word does not occur in isolation (SIYANOVA-CHANTURIA; MARTINEZ, 2014; WILLIAMS, 1998).

Gablasova et al. (2017) observe that collocation can be studied employing two main frameworks. The first is phraseological, which focuses on the semantic relationship between two or more terms, while the second would concentrate on the frequency responsible for drawing evidence on lexical co-occurrence in a corpus. This article takes the first approach as a means of analysing Facebook comments. It is believed that the use of lexical analysis associated with an interpretation in the SFL framework may lead to an in-depth understanding of how the social actors are represented. Such collocational patterns ought to be considered as a single lexical item (SWINNEY; CUTLER, 1979), creating a network of conceptual clusters (WILLIAMS, 1998) that might shed some light of how ideology is instantiated in lexical choices.

Phillips' (1989) research is relevant in the context of this study. The author develops a methodology for the study of aboutness as large-scale regularities that can define our perception of the subject of a text. To achieve its goals, Phillips (1989) performs hierarchical cluster-based computational processing, treating collocated items as a network of macro and micro textual references, plotting a dendrogram that shows the relationships of co-occurrence and hierarchy. 


\section{REVISTA DA ABRALIN}

This research uses Phillips' (1989) model in order to study the lexical clusters in the comments and their collocate patterns in order to interpret them using the transitivity and appraisal frameworks.

\subsection{Data collection, data processing and corpus definition}

Data was collected using Netvizz, ${ }^{5}$ a software that scrapes data form Facebook's pages and communities. The software can scrape information such as posts, comments on posts, general statistics of a page over a period. It only works with pages/communities that have set their status as public and, by default, anonymises usernames as it generates *.tab delimited data files.

All comments were treated using $\mathrm{R}^{6}{ }^{6}$ a statistical software that also offers many packages for working with textual data. $\mathrm{R}$ was a tool for processing clusters, data cleansing and concordancing. The cluster calculation was performed using the Ward's (1963) Hierarchical Grouping Method. Ward (1963) developed a method for creating hierarchical and mutually exclusive groups, in which members tend to be maximally similar concerning a given characteristic. In the case of this research, calculation took into account the co-occurrence of bi-grams (binary relationship) in order to understand how the main topics in the comments were defined in terms of their strongest collocates.

Later, all comments were sorted manually. As any function-based classification, the interpretation of such system of choices is rather subjective - since they might be a result of the one's interaction with his/her contexts of culture and situation (FAWCETT, 2013) - and time consuming since each comment was read a few times in order to validate its classification. Other quantitative studies in SFL (BEDNAREK, 2006; TABOADA; GRIEVE, 2004) also observe that any corpus analysis of the appraisal system would require a great deal of manual classification, with a high degree of subjectivity in the results.

In this study I chose to perform such categorisation with the aid of concordances and collocates in order to observe each bi-gram in context. On the one hand, I believe that such procedure might have minimised possible bias in the sorting, on the other hand, it was responsible for the process to take longer. However, some comments seem to instantiate more than one meaning, a fact which led me to consider some comments as instances of more than one category.

Such a classification aimed at observing how each theme developed in comparison to the word associations calculated earlier. Four main categories were found: 1) those in favour of the quotas, 2) those against the quotas, 3) those bringing some prejudice against Bahia and other Northeast States and 4) those regarding interaction amongst users.

The next step was to generate an ordinary two-gram wordlist of each topic to observe which of such associations were more frequent in the corpus. The five most frequent terms present in the

\footnotetext{
${ }^{5}$ https://wiki.digitalmethods.net/Dmi/ToolNetvizz

${ }^{6}$ https://www.r-project.org
} 


\section{REVISTA DA ABRALIN}

cluster association and at the wordlist were submitted to a matrix association calculation. This association takes the matrix of word co-occurrence and observes the most common via a co-relation (Pearson) test. These words were also submitted for concordancing in order to qualitatively observe their meanings.

Finally, this research followed this algorithm for data collection and analysis:

1. Collecting data from Facebook using Netivizz

2. Anonymise manually all personal data present in the comments

3. Import data into $\mathrm{R}$

4. Process a document term matrix network for the cluster's calculation

5. Calculate and generate clusters visualisation (whole corpus)

6. Manually categorise all comments

7. Calculate and generate clusters visualisation (each subcorpora)

8. Generate wordlists (each subcorpora)

9. Generate concordances for each term studied

All scripts developed for article will be available on-line ${ }^{7}$ for future replicability at the researcher's website at the time of its publication. Unfortunately, data is not made public for ethical reasons.

\begin{tabular}{l|l}
\hline \multicolumn{1}{c}{ Elements } & Values \\
\hline Original Comments & 2647 \\
\hline Tokens & 71788 \\
\hline Types & 63054 \\
\hline Types/tokens ratio & 1.14 \\
\hline Tokens per comment & 27.12 \\
\hline
\end{tabular}

TABLE 1 - Comments statistics

Table 1 shows the general metrics of the corpus. There are 2647 unique comments, more than 70,000 tokens and a little more than 63,000 types. The types/token ratio shows that there some variation in terms of lexis, since most of the comments seem to have mostly unique words.

\section{Results}

The general aboutness of the comments seems to be related to the Brazilian system of quotas (figure 1). Cota (quote) is the more frequent word (3\%) and followed by trans, a short form of transsexual in

\footnotetext{
${ }^{7}$ All scripts will be available at http://www.iel.unicamp.br/rll307 and https://github.com/rll307
} 


\section{REVISTA DA ABRALIN}

BP (1,4\%). Words which seem to identify the discussion social locus, such as the Northeast of Brazil and UFBA and its nature as a public university, and the lack of opportunity of the people the systems of quotas is directed to, seem to occur in smaller numbers.

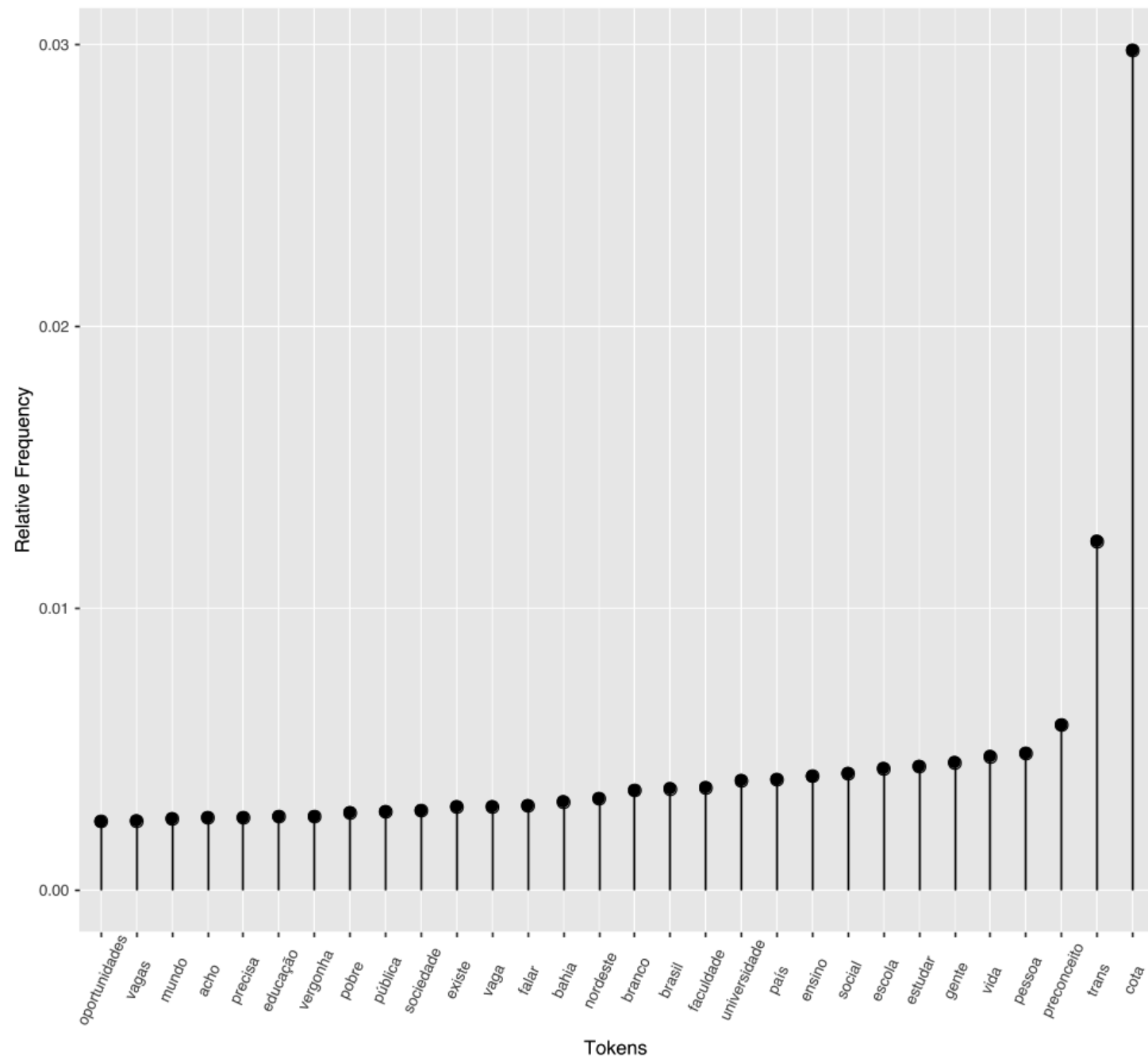

Source: Data

FIGURE 1 - Wordlist of the 30 more frequent words in the general Corpus $(t=24.031, p=2.2 e-16)$

The results are also significant for the t-test regarding the difference between the mean occurrence of such words. This result shows that such choices did not happen by chance; they possibly related to the general topic of the comments. Such topics seem to have four main subjects: the system of quotas itself (e.g. cota, vagas), which includes the transsexuals as the beneficiary of such system (e.g. trans) and the university (e.g. faculdade, universidade, escola) which offers the quotas, the region of Northeast and its citizens (e.g. nordeste, Bahia), negative evaluation (e.g. vergonha), and racial-social issues (e.g. pobre, branco). 


\section{REVISTA DA ABRALIN}

Figure 2 brings a Dendrogram cluster of the whole corpus. The main objective of such representation is to demonstrate how the most frequent words associate. It can bring us a very fair understanding of the aboutness (PHILLIPS, 1989) of such comments as it aids us to understand how the main social actors are discursively characterised.

Ten clusters resulted from the association of the different lexical items. The first cluster consists of three items, in which the expression baixa renda (low income, ex.1) is hierarchically subject to existir (exist, ex. 10). In this cluster, such collocation pattern is a result of the constant reaffirmation of the way the quota system works, as it will be discussed later.

Ex 1 Galera pesquisem existe cota pra quem tem renda baixa Guys, research there is quota for those who have low income Ex 2 Elas são voltadas aos públicos que estão em situação de vulnerabilidade social. They are aimed at audiences who are in a situation of social vulnerability.

Ex 3 @Usuária empregos eu entendo, mas cota pra faculdade é outra história trans ou não, ainda existe o privilégio de cor, classe social etc.

@ User jobs I understand, but quota for college is another trans story or not, there is still the privilege of color, social class etc.

Ex 4 Esse povo tá aqui falando merda das cotas (...)

These people are here talking shit of quotas (...)

Ex 5 (...) como o fato da pessoa ser, trans, negra, indígena diminuisse sua capacidade de entrar em uma universidade (...) it is like if the person is trans black indigenous it would diminish his/her ability to enter in a university

Ex 6 (...) eu branco e pobre e tenho direito a cota de escola pública

(...) I am white and poor and have the right to a public-school quota.

Cluster number 2 seems to bring meanings regarding the access of transsexual groups to the university. The quota system is portrayed as a solution to such an issue, as one might see in choices such as transexual (transsexual, ex.5), preconceito (prejudice, ex.21) entrar (get in, ex.5) and universidade (university, ex.5). Clusters 3 and 4 seem to be related to the escola pública (state school, ex. $6),{ }^{8}$ and it expresses Brazilian free education system as a right of any social end ethnic group. Cluster 5 concerns the life and exclusion of transgender people from the labour market (ex. 40), while number 6 has as its central point the social vulnerability and the relationship between classes (ex. 2).

\footnotetext{
${ }^{8}$ The Brazilian educational system has been undermined for the last 50 years of a policy that has taken away investments and made secondary and primary school teachers underpaid. As an extensive educational crisis emerges in the early 1990s, private schools rise as a solution for the educated Brazilian high and middle classes, but not for the poor. A long-term consequence was that only private school students were able to get the high scores necessary to the entrance in the Brazilian public university system. As a remedial policy, in early 2000 most of the Brazilian universities started to offer quotas for students who have finished their High School (or Secondary Upper School) in any state school. For a more comprehensive discussion on the Brazilian educational crisis, please see Frigotto and Ciavatta (2003).
} 


\section{REVISTA DA ABRALIN}

$0.0 \quad 0.6 \quad 1.2$
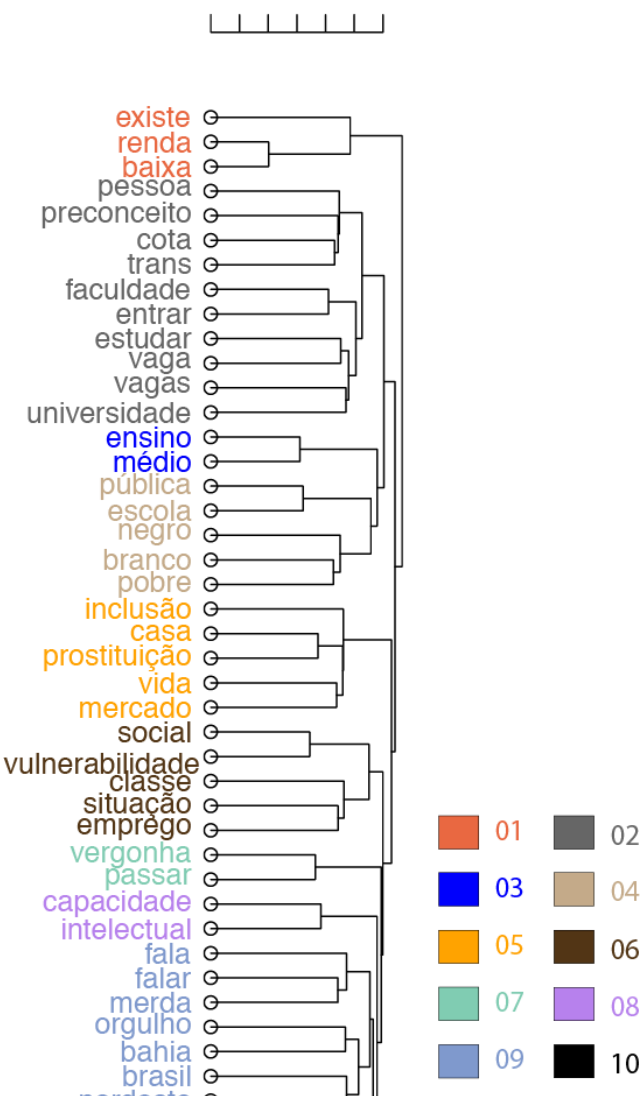

FIGURE 2 - Dendrogram clusters (binary association with Ward's (1963) model) 


\section{REVISTA DA ABRALIN}

Cluster seven expresses opinions about what a particular user has posted, as comments are commonly related to the interaction amongst the speakers than to the quota system itself (ex.19). It is similar in cluster 9, which has a common phraseology in Brazilian Portuguese falar merda (say/talk shit, ex. 4), frequently used in an informal critical tone. This cluster also seems to bring meanings concerning the northeast states, especially Bahia.

Cluster 8 characterises the groups who benefit from quotas as individuals with limited intellectual capacity (ex. 28). Finally, cluster 10 provides an overview of the topics discussed in the posts, regarding race and access to universities. There are several evaluative elements such as clowning (palhaçada), better (melhor) and equal (igual), and processes such as existing (existential), suffering (mental) and understanding (mental). Issues such as sexuality are also present in words like sexual and transsexual. Some terms, such as problem (problema) and access (acesso), seem to justify a negative semantic prosody.

This preliminary cluster analysis seems to reveal that the comments are centred on four main topics: 1) interaction amongst/between users - which focus on way users criticise/slander other users due to lack of knowledge or different opinions regarding the system of quotas -; 2) negative evaluation - which accounts for comments that disprove quotas -; 3) positive evaluation - which stands for comments that evaluate the quotas positively -; and 4) manifestations of pride/prejudice in respect of the Brazilian Northeast states.

These four main groups (table 2) are the topics present in the comments. Interactions amongst users hold the highest numbers (45.5\%) of the total of comments, while negative (24.3\%) and positive (21.4\%) are close to a quarter of the total. Prejudice is the least subject treated in the comments, a little shy form $9 \%$.

\begin{tabular}{|l|c|c|c|c|}
\hline Categories & Comments & \% & Tokens & Types \\
\hline Positive & 567 & 21.42 & 20626 & 15853 \\
\hline Negative & 649 & 24.51 & 20885 & 20885 \\
\hline Prejudice & 225 & 8.5 & 3680 & 4439 \\
\hline Interaction & 1206 & 45.57 & 26597 & 21877 \\
\hline Total & 2647 & 100 & 71788 & 63054 \\
\hline
\end{tabular}

TABLE 2 - Comments categorised by subject

The initial expectations were that positive or negative evaluations would be the more frequent themes discussed in the thread of comments. As table 2 shows, the interaction between the users is the topic with the more significant number of comments, meaning that almost half of what users discussed refers to the opinions that they expressed regarding one another. Each positive and negative opinions are less than a quarter of the total interaction. As the examples will show, more than a place for expressing political views, the comments also were a place for exchanging of personal insults.

The presence of offences and racism towards people from Bahia, and the Northeast, in general, was also an unexpected result. The initial hypothesis was that the questioning of such social quotas 


\section{REVISTA DA ABRALIN}

would take place by the expression of a more conservative view of society but not by intolerance. Although the data collection could not map such comments in terms of their geolocation, the sort of tension they represent might be an indication that users who might have written them are from the southern areas of Brazil.

In terms of word distribution across these categories, the number of types/tokens seems to be disproportional. This so because the theme that produced the more significant number of comments is the one with least number of tokens per comment (figure 3). The positive comments are the ones with the larger number of tokens per comment (36.7 on average), while the negative opinions are the second longer streaming of texts (32.18 in average). Figure 3 also shows that expressions of prejudice against Bahia and Northeast have 19.72 words average.

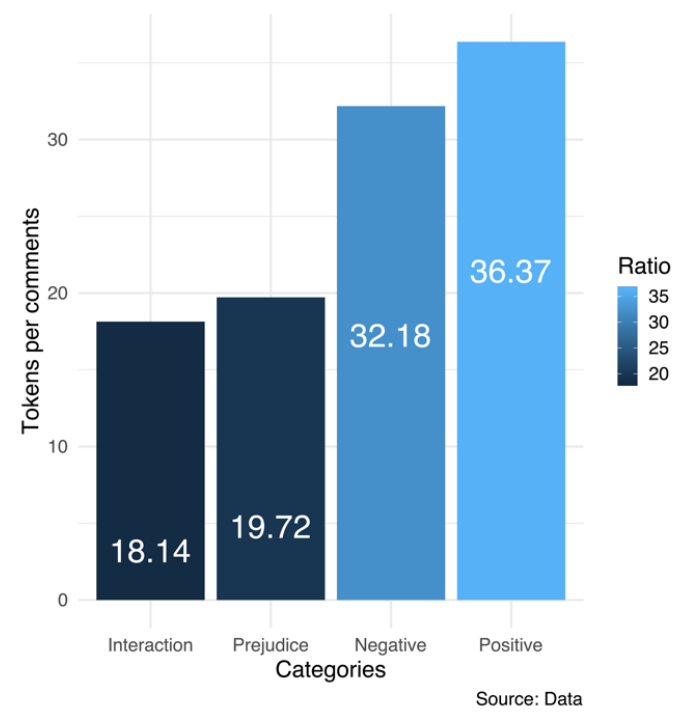

FIGURE 3 - Average distribution of tokens across themes $(t=-2.5118, p=0.06593)$

As one reads through figure 3, positive commenters may make longer texts and have longer pieces of argumentation in favour of their beliefs, it seems that users who are in favour of quotas took more time explaining and making their point of view clear to the reader. As negative interactions are shorter, it is likely their authors took less time in argumentation. Themes as interaction (18.15 average) and prejudice (19.72 average) are similar in terms of size.

The primary hypothesis in the t-test was that theses averages would be different, and, therefore, uncommon. As the results came precisely the opposite, consequently it might indicate that this kind of word distribution seems to be the one expected in interactions like this.

As an outcome of the comparison between table 2 and figure 3, it would be possible to observe that the interaction amongst users is the most common topic discussed, while it is the smaller in terms of text extension. Positive and negative evaluations of UFBA's quotas are quite similar in terms of the number of comments, types and tokens. The results are relevant not only because they show 


\section{REVISTA DA ABRALIN}

the natural polarity that would take place in a context like this, but also suggest that other social themes are relevant in such context.

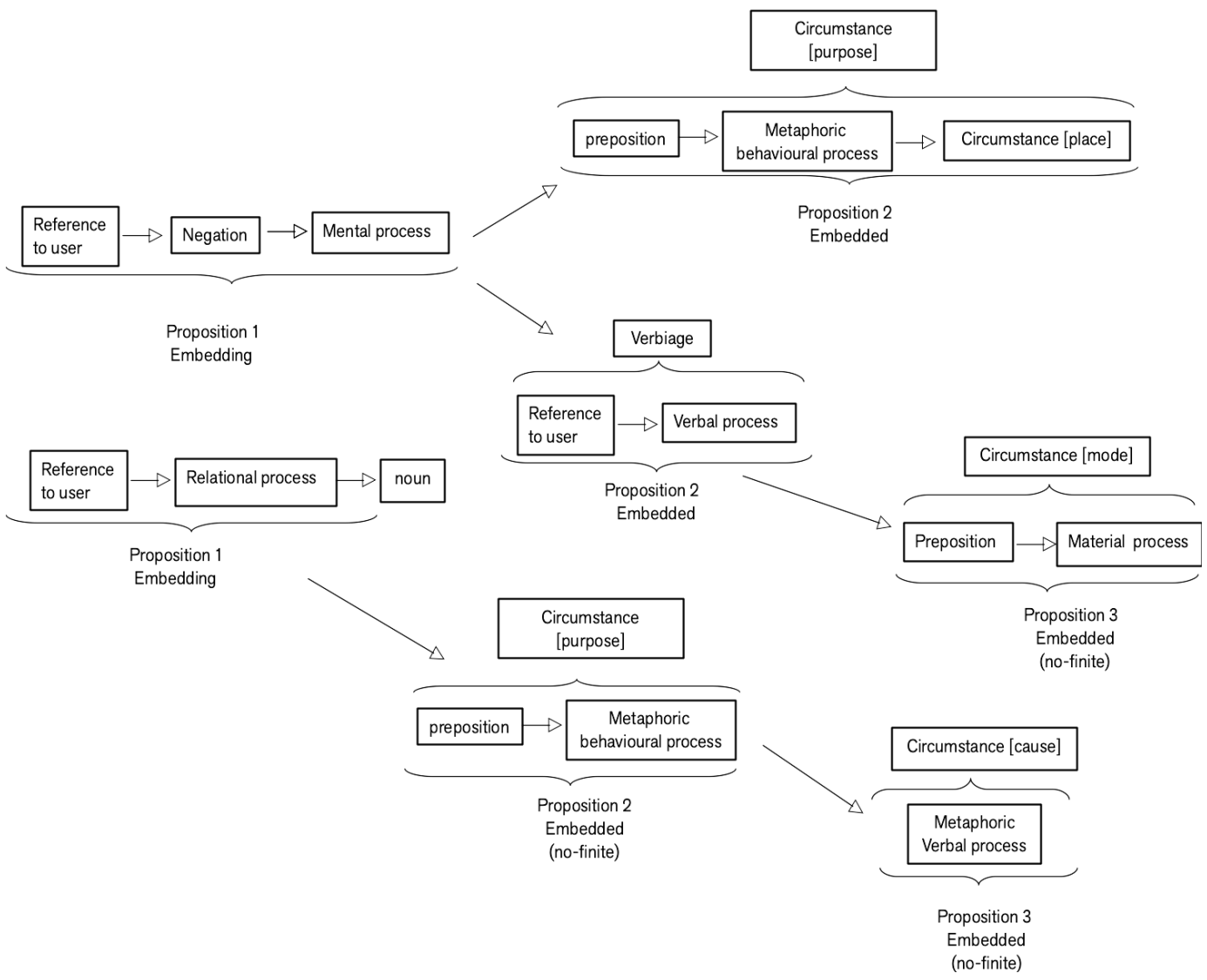

FIGURE 4 - System of choices: interaction amongst users

Interaction amongst users is the more frequent topic in the comments, and four seem to be the most frequent subtopics discussed here: 1) questioning one's knowledge regarding the system of quotas; 2) mocking or insulting users; 3) racial tensions. Figure 4 brings a system of choices that represents such meanings.

As one might see in figure 2, there are direct co-textual expressions, like baixa renda (low income), ex. 8, escola pública (State Schools, ex. 10), which relate to this topic strongly. Such a relationship occurs in comments that defend the socioeconomic criterion as the only acceptable for a quota system. As users express that a low-income programme should exist, they represent system "as it is" as ideologically biased for targeting specific social groups, making the way of the poor in the university more challenging in comparison to the black and transsexuals (ex. 18).

Ex 7 (...) não sou trans, não sou negra, não sou refugiada, mas sou pobre, não posso pagar uma faculdade, tenho direito de cota? 


\section{REVISTA DA ABRALIN}

I'm not trans, I'm not black, I'm not a refugee, but I'm poor, I can't afford a college, do I have the right for quotas? Ex 8 Eu sou a favor sim de cota para baixa renda para TODOS sem distinção de ideologia, cor ou etinia! I agree to the quotas if they are for low-income people disregarding ideology colour or ethnicity

Ex 9 @User amigo as cota servem para pessoas de baixa renda tbm. @User, my friend the quotes are for people of low income too.

Ex 10 Porque ja existe lindo, cota pra pessoa que estudou a vida toda em escola pública Because it already exists, my darling, quotas for those who studied in state schools

On the other hand, these users are criticised for some lack of knowledge regarding the quotas in Brazil, since most of the major universities already offer quotas for underprivileged students (ex. 7, 9,10 and 11). The common strategy is to make this person as a senser in a mental cognitive process. In most of the times, these processes come in the negative form in order to represent the user's incapacity to understand the system of quotas (ex. 11 and 12). The central argument lies in the negative characterisation of such users, who are judged in terms of normality (ex. 11) or appreciation (ex. 14). This appreciation is commonly expressed using adjectives (ex. 11 and 14), while normality is instantiated by either negation (ex. 12 and 13) or imperative (ex. 15).

Ex 11 Tá desinformado hein! Existem cota sociais caso não saiba! You're uninformed huh! There are social quotas if you do not know! Ex 12 vc nao sabe nem o que ta falando pra comecar $\mathrm{U}$ don't even know what you are saying to begin with. Ex 13 (...) esse bicho não estuda kkkkkkk

This animal does not study kkkkkkk

Ex 14 Burro do caralho

Stupid fucking ass

Ex 15 Vá estudar e se informar para não passar vergonha na internet! Study and be informed for not getting ashamed on the internet!

The lack of familiarity with the system is interpreted not only as misinformation (ex. 11) but also as intellectual laziness (ex. 13) or stupidity (ex. 14). Passar vergonha (ex. 15) is also another way to represent this system that brings a strong personal offence, since the unfamiliarity with the system of quotas should be something to ashamed of. In some cases, a response to a comment represents some users as burro (stupid) or as a bicho (animal) in co-occurrence with a cognitive mental (estudar, study, or saber, know), in order to get a general tone of cognitive incapacity in a very negative semantic prosody. Mocking and swearing are also typical strategies and a common trace Brazilian culture for undermining one's argument.

Ex 16 É difícil ser Branco e hetero? Is it hard to be White and Straight? Ex 17 Tadinho do branco sofrido! What a poor white boy!

Examples 16 and 17 represent quite negative feelings towards a "so called racial democracy". They bring traces of irony as they put white people in the shoes of those who suffer prejudices. It is 


\section{REVISTA DA ABRALIN}

possibly a reaction towards a fabricated racial harmony and racial democracy in Brazil (HASENBALG, 2005). According to Hasenbalg (2005), such phenomenon tends to replicate the master-save relationship within a less aggressive discourse. Racism has an economic expression in which black people are present in a subservient social place. This so-called racial democracy is a commonplace in Brazilian traditional mass media (JOYCE, 2012; LIMA-LOPES, 2016), in which white and black live their social roles peacefully. In fact, some white segments of society have historically denied the existence of race related issues since the early $19^{\text {th }}$ century (HASENBALG, 2005).

Example 18 expresses a different framework; it tries to identify the quotas as an attempt to exclude the white male from the educational system. This meaning relies on the use of completamente (completely or entirely) in association with the mental process esquecer (forget) in a context which the white male is the phenomenon in a passive voice.

Ex 18 (...) como as cota[s] são para os pobres, trans e pretos, os machos brancos serão completamente esquecidos! (...) as the quota [s] are for the poor, trans and black, white males will be completely forgotten!

Ex 19 Mais facil reclamar sem saber e passar vergonha do que tentar se informar né It is Easier to complain out of ignorance and be ashamed than trying to find out, right? Ex 20 Tem direito de passar vergonha por falar merda You have the right to be ashamed of talking shit.

Collocates like passar vergonha (be ashamed), ${ }^{9}$ ex. 19, and falar merda (say shit), ex. 20, also express how users interact across the corpus. In most of the cases, the comments are much more related either to cursing or slandering.

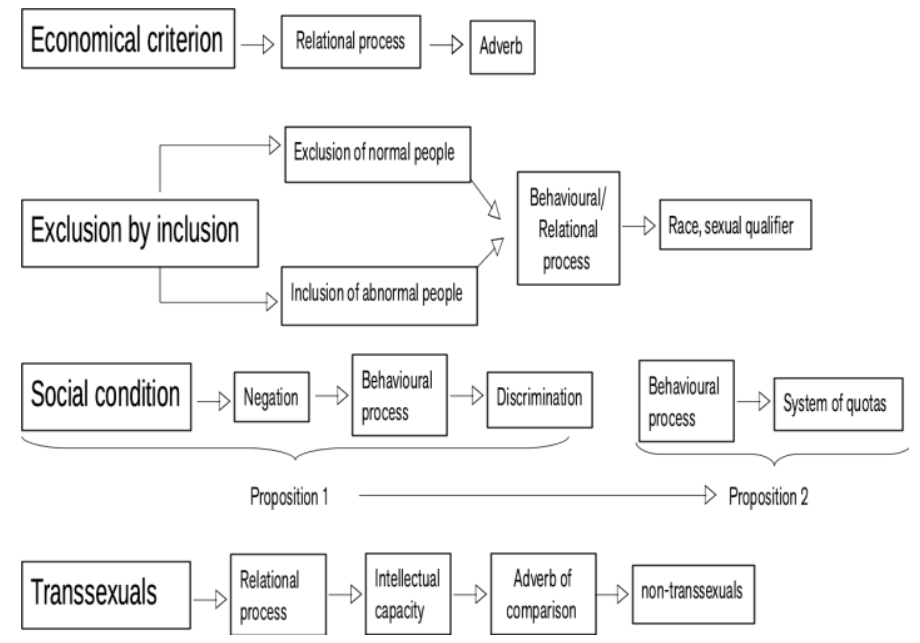

FIGURE 5 - System of choices: negative opinions

\footnotetext{
${ }^{9}$ Passar vergonha (be ashamed) is a figure of speech in Brazilian Portuguese for expressing the feeling of shame that someone should have (but not necessarily has) for not behaving as expected in some situation.
} 


\section{REVISTA DA ABRALIN}

The negative evaluation of the quotas is commonly related to three main topics: (1) that minority groups should not be eligible for such policy (ex.21); (2) that is a means of exclusion of white people (Ex. 25 and 26) and (3) that the minorities might be characterised as less capable (ex. 27). Figure 5 brings a system of choices that represents such meanings.

Firstly, comments discuss weather suffering discrimination and social vulnerability are acceptable criteria for quotas. In this context, the primary strategy is to make jokes by comparing such groups to other groups who might also suffer some sort of prejudice in order to under evaluate the problems of the people who quotas would benefit.

Ex 21 Por sofrer preconceito essas pessoas merecem uma facilidade pra entrar na faculdade? Because of prejudice, do these people deserve an easier way to enter in college? Ex $22 \mathrm{E}$ os gordos? Pras pessoas com orelha de abano? Se a desculpa é quem sofre discriminação ter cota How about quotas for fat people? For people with big ears? If the excuse is for quotas is a person to suffer prejudice/bulling(...)

Ex 23 Daqui a pouco pra entrar na universidade só se for negro, mulher, gay (...)

Soon you will enter the university only if you are black, woman, gay (...)

Examples ex.21 through 23 bring a refined system of disagreement which is typical of Brazilian Portuguese. Merecer (deserve) is present in an interrogative sentence and is associated with por (for/because) in propositions that bring a sarcastic tone. Characteristics such as gordo (fat) or orelha de abano (big ears) are physical features that represent the quota programmes as overprotective (ex. 31) by creating excuses for making their way into the university easier (ex.21). Propositions like ex. 22 compares different kinds of prejudice in order to argue in favour of the irrelevance of affirmative policies. The strategy is to associate expressions like Se a desculpa (if the excuse) to relational possessive processes like ter (have) to minimise the social issues that serve as a justification for the system of quotas, ex. 22. In this context Sofrer (suffer), ex. 22, is a behavioural process responsible for an important sense of irony.

In the context of UFBA's announcement, comments like ex. 16, 17, 18 and 23 tend to be a response to previous aggressions. Example 23 raises racial and gender issues, since women, black and gay are represented as people who should not belong in the university. A consequence of such quotas would be the exclusion white male from the higher education, a place which belongs to him as his right. Processes, adverbs and adjectives seem to have an important role expressing prejudice (ex. 23 and 18) and reaction to hostilities (ex. 16 and 17). Tadinho (what a poor, in an approximate translation) and dificil (difficult) express racial tensions, they evaluate people who are against the quotas by ironically comparing white people privileges to the difficulties fought by black and trans people. Example 18 uses the modalisation expression and the relational process ser (to be) determine the fact of being part of some of these groups should be mandatory in order to be in a university. The general tone in example 23 is negative, more likely due to two adverbs daqui a pouco (soon) and só se (only if): the first projects a near future motivated by the growth of the quotas, while the latter excludes those who are not part of minority groups. 


\section{REVISTA DA ABRALIN}

Ex 24 Eu não sabia que ser trans, refugiado ou pobre ou negro, tornasse alguém com limitações intelectuais (...) I did not know that being trans, refugee or poor or black would impose someone any intellectual limitation (...) Ex 25 Estou me sentindo excluída de tanta inclusão! Sou branca, idosa, heterosexual (...) I'm feeling excluded because of so much inclusion! I am white, elder, heterosexual (...)

In this discourse framework, the quota system represents a form of exclusion, since white people would be gradually rejected from the university for not participating in affirmative programmes. In most cases, this occurs through a reaffirmation of personal characteristics (ex. 25), as an explanation for not being part of the groups covered by the quotas. This strategy tires to generate a paradox: the absence of some racial, gender and transexual characteristics defines a pessoa normal (normal person), ex. 26, who would be disqualified for joining the university. In Brazilian Portuguese, pessoa normal (normal person) is a high evaluative expression, it praises the superiority of those who belong to it while it disregards all other people.

Circumstantial elements may be responsible for expressing attitude towards the quota system (ex. 25), a possible exclusion caused by the inclusion of those who were not at university before the quota's introduction. This grammatical and discursive strategy seems to build a new ideological representation: people who are now included would be responsible for excluding the ones who were already at university before them. It makes the system to look unfair in the eyes of the privileged white classes.

In Brazilian Portuguese, the future tense of ser (to be) (ex. 26), projects a clause instantiating a verbal form (ir(go)[present]+infinitive verb) meaning a possible and negative hypothetical future (ex. 26). Such a use demands some parallelism between the two verbal forms: ser and ir+verb must both be singular forms in the third person, while the future tense (será, will/going to) projects future meanings in the auxiliar verb (vai, goes/is going to) (ex. 26). Since BP is a pro-drop language, the process is impersonalised by the use of the singular third person inflection. On the one hand, such a grammatical choice reaffirms the feeling of exclusion by making it more objective and impersonal for those who read it; on the other, it pictures the exclusion as a "logical consequence".

Ex 26 Será q vai sobrar vaga pra alguém em situação "normal"? I wonder if Will there be a place for someone in a "normal" situation?

Ex 27 Sou a favor de cota socioeconômicas, sou branco, pobre, morei minha vida toda em comunidade, comecei a trabalhar adolescente, terminei meu 2 grau em um supletivo por não ter tempo pra estudar, quando prestei vestibular não tive direito a nenhuma cota,você acha isso justo ?!?!

I am in favour of socioeconomic quota, I am white, poor, I lived all my life in community, I started working as a teenager, I finished my high school in a supplementary course because I had no time to study, when I took the entrance exam I did not have any quota, you think is that fair?!?!

Transsexuals are ironically represented as intellectually handicapped (ex. 27, 28, 29). In the context of these examples, relational processes (ser, to be) and some material (morar, live, trabalhar, work) and their relationship with some circumstantial elements (em um supletivo, in a supplementary course) are essential because they are used to characterize the user in socioeconomic terms (ex. 27). 


\section{REVISTA DA ABRALIN}

From his/her characterization as an individual belonging to a specific social group (ex. 27), the user also identifies him/herself as authorised to perform a negative view of the system. Relational processes also take an important role, since they seem to relate the irony of these comments: transsexuals are always the possessors of such disabilities (ex. 28 and 29). In this context, the use of some modal verbs - pode (can/might ex. 28) and tem que (must/have to) (ex. 29) - bring a sense of indeterminacy/obligation to the irony.

Ex 28 Transexuais e etc Pode ter uma capacidade intelectual menor do que as outras pessoas? Transsexuals etc. Do they have less intellectual capacity than other people?

Ex 29 Primeiro tem que ter capacidade intelectual

First of all, you have to have the intellectual capacity

Ex 30 Refugiados eu entendo, mas gay ou transgênicos não entendo porque.

Refugees I understand, but gay or transgenic do not understand why.

There were just a few references to refugees (66 occurrences) and immigrants (12 occurrences) in the comments, they are present almost exclusively in comments that criticise the quota system. This brings up an important finding: the discussion motivated by the post is focused mainly on racial issues (black vs. white) and gender identity (transgender vs. cisgender).

Ex 31 Refugiados é compreensível, agora, para as outras já é uma sacanagem Refugees is understandable, now, to others is a joke

Ex 32 A! vsf Cota pra travesti ok Agora pra refugiado já é demais.

Ah! GFY Quota for transvestite ok Now for refugee is too much.

Já (already in a loose translation - ex. 31 and 32) plays an important comparative role in the comments. In Brazilian Portuguese, one of já uses defines that some attitude might be over the expected social limits. In this context, one of these groups (either transvestites/transexuals or immigrants/refugees) is represented as the acceptable limit, while the inclusion of the other in the programme symbolises it has gone too far. Example 31 evaluates the quotas for refugees positively, while the others (representing black people, transexuals and transvestites) are "too much". In example 32, the strategy is to evaluate the quotas for transexuals and transvestites positively in comparison to refugees, who are a "joke". In semantic terms, both groups might be evaluated positively or negatively: the same strategy is present in propositions in favour or against the inclusion of both groups. In grammatical terms, já collocates with a relational process, ser (to be) and an evaluative adverb (demais, too much) or noun (sacanagem, ${ }^{10}$ joke in a loose translation).

Ex 33 Falta dinheiro para nós, mas imigrantes são os privilegiados? There is no money for us, but are immigrants privileged?

\footnotetext{
${ }^{10}$ Sacanagem is a noun that might have many possible meanings in Brazilian Portuguese. In this context, it might be a tentative to fool someone without getting ashamed of it.
} 


\section{REVISTA DA ABRALIN}

Ex 34 (...) um transexual ou refugiado tem mais direito do que os filhos de nós trabalhadores? (...) does a transgender or refugee have more rights than the children of us workers? Ex 35 Um transexual ou um imigrante é menos inteligente que o brasileiro médio?? Is a transsexual or an immigrant less intelligent than the average Brazilian??

Transvestites/transexuals and immigrants/refugees might be treated as privileged, both draining resources that should be directed to the 'normal people' (ex. 33, 34 and 35). Some grammatical patterns emerge in this context, as trabalhores (workers ex. 34) are comparatively portrayed as having less privileges than quota-beneficiaries, as the adverb menos (less, ex. 34) modifies ter (have), a relational possessive process. The use of nós (us/we ex. 33) tends to exclude transexuals and refugees, ascribing them the role of not deserving such affirmative actions. Here nós (us/we ex. 33) plays the role of client in a material process (faltar, lack ex. 33), which has a negative semantic prosody in $\mathrm{BP}$, while immigrants play the role of carriers in attributional relational processes (ser, to be ex. 33). Relational attributive processes are also present in comparative propositions that question the intelligence of quota beneficiaries, who are portrayed as less intelligent (menos inteligentes, ex. 35), and, consequently, below the Brazilian average levels of intelligence.

The discourse in favour of the quota system recognises the problems faced by vulnerable communities it is intended to aid. The main argument takes the prejudice they suffer in their lifetime as causing exclusion from Brazilian educational system, thus moving them away from labour opportunities. Figure 6 brings a system of choices that represents such meanings.

The propositions have their most common focus in the transsexual population, as they try to portray them as victims of some form of social inequity. This occurs in propositions in which the idea of intellectual inability is denied (ex. 36), inasmuch as their social vulnerability is hold responsible for making their lives harder. Relational clauses play an important role in this meaning framework, as they define the system of quotas as responsible for correcting social injustice (ex. 37). 


\section{REVISTA DA ABRALIN}

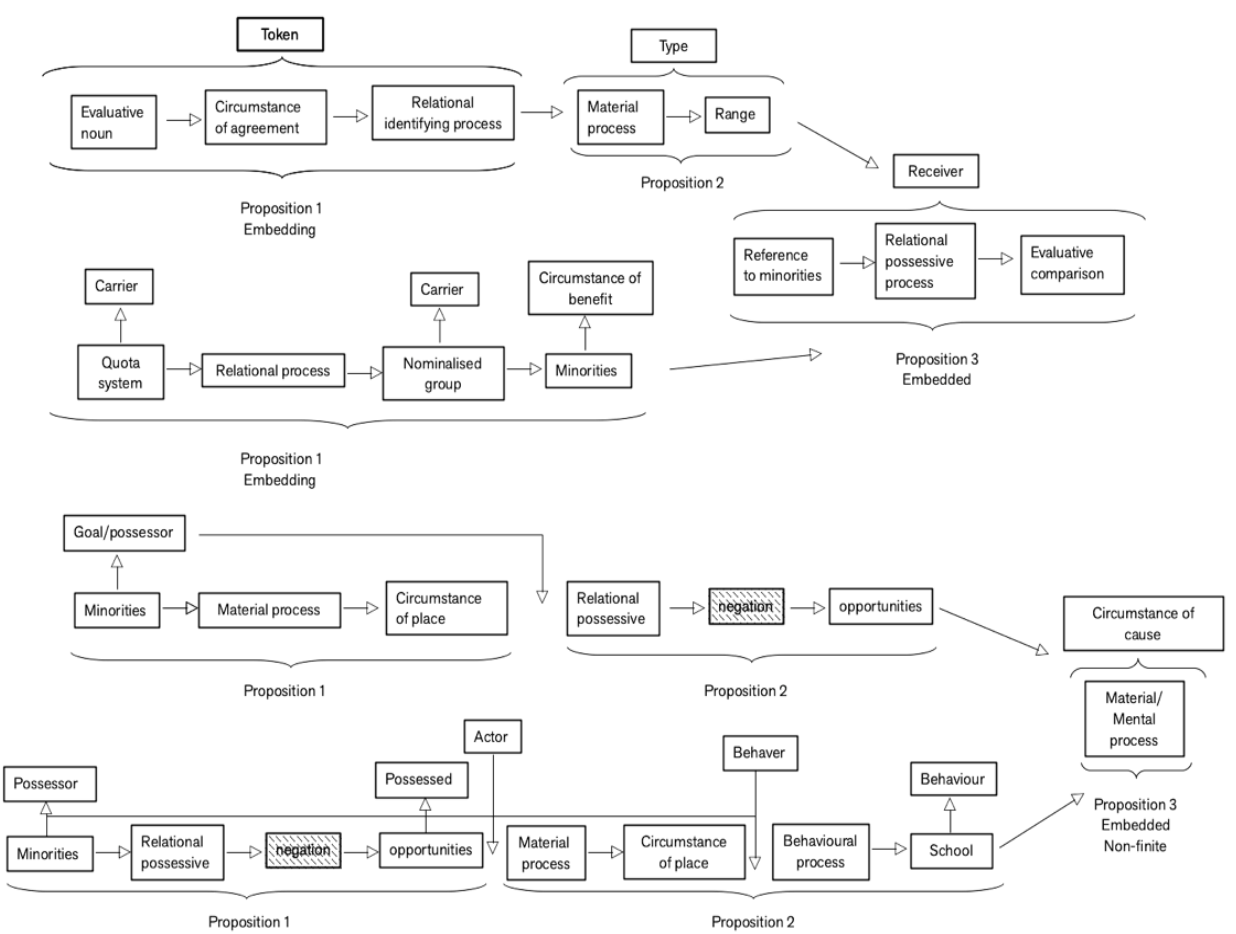

FIGURE 6 - System of choices: positive opinions

Ex 36 Cota é um sistema de inclusão com aqueles que não tem a vida tão fácil quanto a nossa (...)

Quota is an inclusion system for those who do not have a life as easy as ours (...)

Ex 37 (...) as cota pra transexuais servem para combater esse problema de desigualdade e inclusão de transexuais no mercado de trabalho e universidades.

Quotas for transsexuals are important to fight this problem of inequality and inclusion of transsexuals in the labour market and universities.

Ex 38 (...) os trans não têm as mesmas oportunidades pois são excluídos da sociedade e muitos não conseguem seguir os estudos por sofrer transfobia (...)

(...) transgender people do not have the same opportunities because they are excluded from society and many cannot follow their studies because they suffer transphobia.

Transexuais (transsexuals) (ex. 37) or pessoas (people) (ex. 39) are beneficiaries (receivers) (ex.39) or goals (ex. 38) in material processes, as well as possessors in relational processes (ex. 40). Such grammatical pattern represents them as eligible for quotas as they have fewer opportunities and are subjected to prejudice during their lifetime (ex. 36, 37 and 38). Circumstances of place (ex. 37) and cause (ex. 38) are responsible for including other participants in the proposition - labour market, transphobia etc. - in order to represent quotas as a reparation for their exclusion from society. The circumstances are, most of the times, complex including verbal nominalisation inclusão (inclusion, 


\section{REVISTA DA ABRALIN}

ex. 37) - from incluir (include) - or hypotaxis por sofrer ${ }^{11}$ (because they suffer, in a free translation, ex. 38) as they are responsible for the semantic prosody within the proposition. The processes are also evaluative, since sofrer and incluir carry strong cultural meanings, the first brings a negative prosody which contrasts and validates the need for affirmative polices, while latter takes an idea that the society should incorporate minorities.

Relational possessive processes establish a relationship between minorities and the need for inclusion. Transexuals are related lexical items as like mesmas oportunidades (same opportunity, (ex. 38) and dificuldade (difficulty) (ex. 40), always expressing some non-positive evaluation. Negative propositions play an essential role, the wording reflects the verb in its negative form as well as adverbs that modify the process and bring about a negative meaning in BP.

Ex 39 Parabéns, é assim q se faz inclusão dando oportunidade as pessoas que não tiveram Congratulations, this is how inclusion is done by giving an opportunity to people who have not had.

Ex 40 Mulheres trans têm muita dificuldade pra arrumar emprego, muitas desistem de estudar devido ao preconceito.

Trans women have a hard time getting a job, many give up studying due to prejudice

Ex 41 Travestis e transsexuais são expulsos de casa, não têm condições de sobreviver e estudar Transvestites and transsexuals are sent away from from home, unable to survive and study

Ex 42 Vc sabia que 7 de cada 10 trans acabam caindo na prostituição por não ter acesso ao mercado de trabalho? Did you know that 7 out of 10 trans end up into prostitution for not having access to the job market?

There are few material processes in which transexuals are goals (ex. 40, 41 and 42), typical examples are cair (to fall) and expulsar (to send away from) (ex. 41 and 42). Expulsar (ex. 41) sets the interpretation background to with ter (have): transexuals are goals in a transformative material process that are in parataxis with a negative relational possessive process which defines their lack of options and their school dropout. Elseways, cair, a delexicalized process that depends mostly on the circumstantial element (na prostituição, into prostitution, ex. 42), represents transexuals as unable to take a different path due to the prejudice which drives them to prostitution. Some similar pattern is present in Desistir (to give up, ex. 40), a behavioural process which much of the prosody comes from ter (have, ex. 40). This parataxic meaning of cause vs. consequence seems to be an outcome of the semantic relationship that the processes establish, as they create a wave of appraisal choices that work as justification for the quotas.

As we can notice from examples 43 and 44, the comments evaluate UFBA as a provider of a new and excellent service for the transsexual community, to whom this sort of programme might be an important benefit (ex. 45).

Ex 43 Ações como esta da universidade da Bahia proporcionam maior igualdade às oportunidades de ensino. Programmes like this one at the University of Bahia provide greater equality of teaching opportunities.

\footnotetext{
${ }^{11}$ Por sofrer is a reduced adverbial of infinitive proposition in BP. Such a structure is possible because prepositions followed by verbs have to be followed by an impersonal form of infinitive.
} 


\section{REVISTA DA ABRALIN}

Ex 44 No país da desigualdade, cota é o mínimo pra tentar começar a mudar isso (...) In the country of inequality, quota is the minimum to try to start changing this (...)

Ex 45 Negro sofre preconceito? Sim Viado sofre preconceito? Sim Pobre? Muito também mas nenhuma classe é tão marginalizada quando as trans

Do the black people suffer prejudice? Yes! Does a queer suffer prejudice? Yes! Poor? Yes, very much but, no class is so marginalized as transsexuals

As I have discussed earlier, a result that drew my attention during data analysis was the presence of attacks against some ethnic and social groups as well as some expression of proud for being part of these very groups. Figure 7 brings a system of choices that represents such meanings.

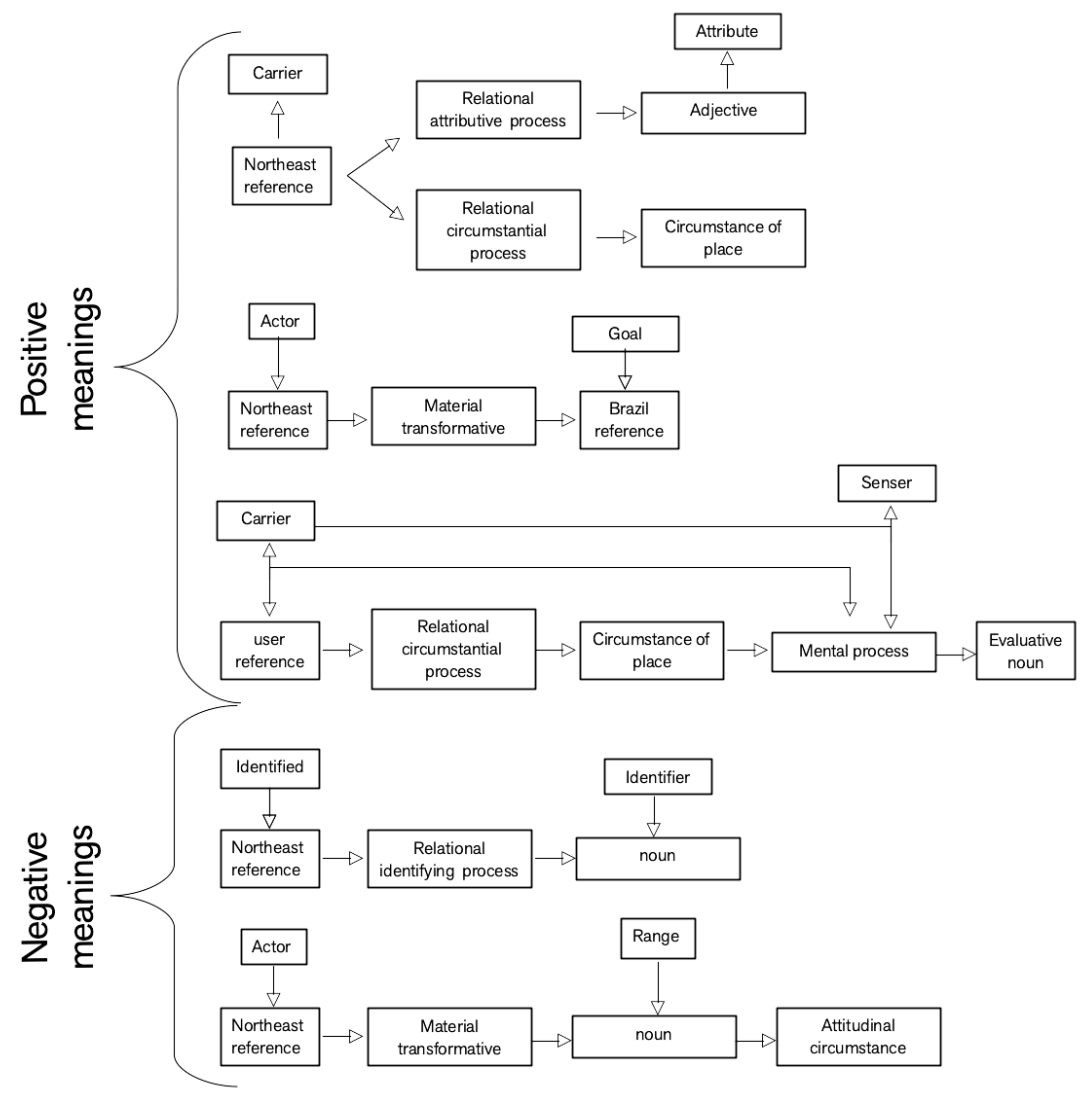

FIGURE 7 - System of choices: prejudice/pride

Attacks are primarily against the residents of Brazilian Northeast, where UFBA is located, and they express racial/social tensions amongst users by questioning the way that the quota programme is organised. Examples 46 and 48 instantiate common negative meanings. The first advocates that the Northeast should not be part of the country, while the second ascribes a meaning of shame to the region. Northeast is represented as a goal in a material process (ex. 46) without a clear actor, a pattern represents a modalisation strategy in most of the propositions in which this meaning is present. As 


\section{REVISTA DA ABRALIN}

Northeast states should be excluded from Brazil, o resto do pais (the rest of the country) actualises a role of circumstance of place within the proposition and it is indirectly ascribed the role of actor.

Rachar a cara de vergonha (ex. 48) is a Brazilian expression for getting oneself ashamed, or for bringing shame to oneself without necessarily noticing it. The proposition instantiates a material process (rachar), ${ }^{12}$ a goal (cara, face) and an attitudinal circumstance (de vergonha, of shame) in order to actualise such meaning. In interpersonal and ideational terms, it should be considered a single lexical package, actualising a very complex and cultural judgment towards the states of Northeast.

Ex 46 eu também gostaria que o Nordeste fosse separado do resto do país (...)

I would also like the Northeast to be separated from the rest of the country (...)

Ex 47 Meu país nordeste é top!!!

My northeast country is the best!!!

Ex 48 Nordeste rachando a cara de vergonha novamente.

Northeast full of shame again.

The expression of prejudice seems to be related to both aggression Bahia and other northeast states (ex. 49, 50 and 51). Much of the aggression is not related to the quota system, but to geographic-racial tensions between the South and the Northeast of the country. In some propositions, Bahia (ex. 49) is a superordinate of all Northeast states, which denotes a rather offensive way of representation. The irony is common, it usually combines the use of material and behavioural processes followed by a circumstantial element that indicates an attitude. The idea is to establish a semantic prosody in which Bahia (and all the Northeast States) should not be taken seriously.

Example 49 is an attempt to make the quotas sound ridiculous. The user actualises the Actor in two material process mudar (move)/ganhar (win/get) and the behaver in a behavioural process usar (wear). Bahia and quotas are present in a circumstance of location or play the goal, respectively. The circumstance of mode de leve (easily) plays and important role in the ironical approach, as it represents how easy would that be.

Ex 49 Vou mudar pra Bahia e usar batom, ganhar uma cota de leve (...)

I'll move to Bahia and use lipstick, get quota easily (...)

Ex 50 Por isso que é os estados mais fodido (...)

That's why it's the most fucked up states (...)

Ex 51 Vocês [nordestinos] são estados QUEBRADO (...)

You [nordestinos] are BROKEN states (...)

Economic disputes are a relevant thematic element. In this context, the Northeast play the role of Carrier in relational attributives processes in order to represent it as economically dependent on the South (ex. 50 and 51). Adjectives are a means to evaluate some states negatively - quebrado

\footnotetext{
${ }^{12}$ Rachar could be translated literally as to crack, but since its use in this context is somewhat metaphorical, I have chosen to keep the original meaning in Portuguese.
} 


\section{REVISTA DA ABRALIN}

(broken), fodido (fucked up) -, while others - like primeiro mundo (first world) - and praise the economic development of the South. The use of all caps (QUEBRADO, broken) also brings a critical evaluative stance, since they represent shouting in internet language.

Some comments are reactions to the prejudice, they commonly are responses to other comments, and they praise the state of Bahia or the Northeast region. Such pride is expressed by identifying relational processes, in which Bahia plays the type while another noun (like pais, country (ex.52) which plays the role of token. Mental processes of affection are also common choices, the user plays the Senser (ex. 54), while nordeste (Northeast), or any other state, plays the phenomenon. In some cases, both Bahia and Nordeste also actualise the role of behaver in a process which the beneficiary is the whole country (ex.53).

Ex 52 A Bahia é o meu país!

Bahia is my country!

Ex 53 E, mais uma vez, o Nordeste salva o país

And once again, the Northeast saves the country

Ex 54 Por isso eu amo o Nordeste

That's why I love the Northeast

Ex 55 (...) não sou da Bahia, mas senti orgulho!

(...) I am not from Bahia, but I was proud!

Ex 56 Infelizmente nasci no estado do preconceito Grande do Sul.

Unfortunately, I was born in the state of prejudice Grande do Sul.

Users also express shame and pride simultaneously, as they describe themselves as not originally from Bahia or the Northeast region however showing some admiration for the quotas system (ex. 55 and 56). Two grammatical patterns express this meaning. First, there is a parataxis relationship in which the first sentence identifies the origin of the speaker, while the second establishes the positive evaluation. The second brings a modalisation adverb at the beginning of the comment followed by the location of origin, usually expressed by a material process (ex. 56), a typical configuration in BP.

\section{Final remarks}

This article aimed at studying choices in comments made on Facebook at the time of the announcement that the quota system at the Federal University of Bahia would include immigrants, transsexuals, refugees and transvestites. The theoretical foundations are in Systemic-Functional Linguistics and Corpus Linguistics. The first provided the interpretative background necessary for understanding meanings and patterns, while the second was responsible for the systematic survey of language patterns.

The methodology was based on data scraping and automatic processing. Scraping was performed using the Netvizz, while processing was performed using R programming language. Word 


\section{REVISTA DA ABRALIN}

lists were created, and statistical tests of significance were applied, while the resulting lexis was analysed using concordances. A document term matrix network chart for the cluster's calculation was created from binary association.

Lexical association was an important tool, as hierarchical association between clusters defined the main themes in within the comments. The main themes discussed are the interaction of users, the role of the public school and the quota system, as well as prejudice against universities and states of the Brazilian Northeast. It was observed that the interaction between users is centred on offences questioning the unawareness regarding the quota system. The negative evaluation is instantiated in three main discursive patterns. In the first, there is a criticism of any policy that is not based on a socioeconomic criterion, while the second arises from the interpretation of this system as necessarily excluding the heterosexual and white population. Finally, the situation of social vulnerability is not considered a valid criterion. The system positive evaluation lies on the perception that they would be a reparation or form of inclusion to the minorities. Prejudice against UFBA, North-eastern states and their citizens manifests itself through economic issues or evaluations that place such states and institutions as not serious. Manifestation of pride for Bahia, Northeast and the system of quotas is the common reaction to such prejudice. Some grammatical patterns regarding each of these most common meanings were systematised (figures 4 through 7) and their relevance is in helping to understand how the different themes are instantiated.

This research has important social contributions, since shed some light in the way interaction occurs on social media, especially in contexts of political debates. This paper is corroborating some others already carried out in BP (LIMA-LOPES, 2018; MERCURI; LIMA-LOPES, 2020), observing the need for research on the of daily political discourse.

\section{Acknowledgments}

I would like to thank CNPq for the funding that made this research possible (process 422111/2018-0).

\section{REFERENCES}

ALBA-JUEZ, L.; THOMPSON, G. The many faces and phases of evaluation. In: THOMPSON, G.; ALBA-JUEZ, L. (Eds.) Evaluation in context. Pragmatics \& beyond new series. Amsterdam; Philadelphia: John Benjamins Publishing Company, 2014. p. 3-27.

ALMEIDA, R. DE Q. Fake news: arma potente na batalha de narrativas das eleições 2018. Ciência e Cultura, v. 70 , n. 2, p. 9-12, abr. 2018.

BANKS, W. P. Beyond Modality. In: ALEXANDER, J.; RHODES, J. (Eds.) The Routledge Handbook of Digital Writing and Rhetoric. 1. ed. [s.1.] Routledge, 2018. p. 341-351. 


\section{REVISTA DA ABRALIN}

BEAUGRANDE, R. Descriptive linguistics at the millennium: Corpus data as authentic language. Journal of Language and Linguistics, v. 1, n. 2, p. 91-131, 2002.

BEDNAREK, M. Evaluation in media discourse analysis of a newspaper corpus. London: Continuum, 2006. BEN-DAVID, A.; MATAMOROS-FERNANDEZ, A. Hate Speech and Covert Discrimination on Social Media: Monitoring the Facebook Pages of Extreme-Right Political Parties in Spain. International Journal of Communication, v. 10, p. 1167-1193, 2016.

BIBER, D.; CONRAD, S.; REPPEN, R. Corpus linguistics: investigating language structure and use. Cambridge; New York: Cambridge University Press, 1998.

ELLISON, N. B.; BOYD, D. Sociality through Social Network Sites. In: DUTTON, W. H. (Ed.) The Oxford Handbook of Internet Studies. Oxford Handbooks. Oxford/New York: Oxford University Press, 2013.

FAWCETT, R. P. Choice and choosing in Systemic Functional Grammar: What is it and how is it done? In: FONTAINE, L.; BARTLETT, T.; OGRADY, G. (Eds.) Systemic Functional Linguistics: Exploring Choice. Cambridge: Cambridge University Press, 2013. p. 115-134

FRIGOTTO, G.; CIAVATTA, M. Educação básica no Brasil na década de 1990: subordinação ativa e consentida à lógica do mercado. Educação \& sociedade, v. 24, n. 82, 2003.

GABARDO, M.; LIMA-LOPES, R. E. DE. Ni una menos: ciência das redes e análise de um coletivo feminista. Humanidades E Inovação, v. 5, n. 3, p. 44-58, 2018.

GABLASOVA, D.; BREZINA, V.; MCENERY, T. Collocations in Corpus-Based Language Learning Research: Identifying, Comparing, and Interpreting the Evidence: Collocations in Corpus-Based Language Learning Research. Language Learning, v. 67, n. S1, p. 155-179, 2017.

HALLIDAY, M. A. K. An introduction to functional grammar. London: Arnold, 1994.

HALLIDAY, M. A. K. New Ways of Meaning: The Challenge to Applied Linguistics. In: On language and linguistics. Collected works of M. A. K. Halliday. London: Continuum, 2003. p. 139-176.

HALLIDAY, M. A. K. An Introduction to Functional Grammar. London: Arnold, 2004.

HALLIDAY, M. A. K. Computational and quantitative studies. London: Continuum, 2005.

HALLIDAY, M. A. K.; HASAN, R. Language, context and text: aspects of language in a social-semiotic perspective. Oxford: Oxford University Press, 1991.

HALLIDAY, M. A. K.; MATTHIESSEN, C. M. I. M. Halliday's introduction to functional grammar. Fourth Edition ed. Milton Park, Abingdon, Oxon: Routledge, 2014.

HASAN, R. Towards a paradigmatic description of context: systems, metafunctions, and semantics. Functional Linguistics, v. 1, n. 9, p. 1-54, 2014.

HASENBALG, C. A. Discriminação e desigualdades raciais no Brasil. Belo Horizonte; Rio de Janeiro: Editora UFMG; IUPERJ, 2005.

HUNSTON, S.; THOMPSON, G. Evaluation: An introduction. In: THOMPSON, G.; HUNSTON, S. (Eds.) Evaluation in text: authorial stance and the construction of discourse. Oxford: Oxford University Press, 2000. p. 1-25. 


\section{REVISTA DA ABRALIN}

JOYCE, S. N. Brazilian Telenovelas and the Myth of Racial Democracy. Lanham: Lexington Books, 2012.

KRESS, G. Against Arbitrariness: The Social Production of the Sign as a Foundational Issue in Critical Discourse Analysis. Discourse \& Society, v. 4, n. 2, p. 169-191, 1993.

LAZER, D. M. J. et al. The science of fake news. Science, v. 359, n. 6380, p. 1094-1096, 2018.

LIMA-LOPES, R. E. DE. Some reflections upon Internet TV in the Brazilian context. New Review of Hypermedia and Multimedia, v. 22, n. 4, p. 2-21, 2016.

LIMA-LOPES, R. E. DE. O Conservadorismo como ideologia: Contribuições da ciência das redes para a linguística sistêmico funcional. Letras, v. 28, n. 56, p. 43-69, 2018.

LIMA-LOPES, R. E. DE. Artes, Militância e Ciência das Redes. Letras em Revista, v. 10, n. 01, p. 141-156, 2019.

LIMA-LOPES, R. E. DE; CÂMARA, M. T. Arco-íris na cruz: a multimodalidade no midiativismo em vídeos no YouTube. Policromias - Revista de Estudos do Discurso, Imagem e Som, v. 4, n. 2, p. 78-102, 2019.

LIMA-LOPES, R. E. DE; GABARDO, M. Ni una menos: A luta pelos direitos das mulheres na Argentina e suas representações no Facebook. Revista Brasileira de Linguística Aplicada, v. 19, n. 4, p. 801-824, 2019.

LIMA-LOPES, R. E. DE; PIMENTA, I. \#Mulheresnofutebol: transitividade e avaliatividade na identificação de padrões sexistas. Humanidades \& Inovação, v. 4, n. 6, p. 116-132, 2017.

MACEDO, K. T. M. Conflitos sociais contemporâneos: possíveis causas e consequências dos linchamentos virtuais. Humanidades \& Inovação, v. 5, n. 4, p. 197-208, 4 jul. 2018.

MARTIN, J. R. Meaning matters: a short history of systemic functional linguistics. Word, v. 62, n. 1, p. 35-58, 2016.

MARTIN, J. R.; ROSE, D. Working with discourse: meaning beyond the clause. London/New York: Continuum, 2003.

MARTIN, J. R.; WHITE, P. R. R. The language of evaluation: appraisal in English. New York: Palgrave Macmillan, 2005.

MERCURI, K. T.; LIMA-LOPES, R. E. DE. Discurso de ódio em mídias sociais como estratégia de persuasão popular. Trabalhos em Linguística Aplicada, v. 59, n. 2, p. 1216-1238, ago. 2020.

OTTONI, R. et al. Analyzing Right-wing YouTube Channels: Hate, Violence and Discrimination. Proceedings of the 10th ACM Conference on Web Science - WebSci '18. Anais... In: THE 10TH ACM CONFERENCE. Amsterdam, Netherlands: ACM Press, 2018Disponível em: <http://dl.acm.org/citation.cfm?doid=3201064.3201081>. Acesso em: 19 set. 2018

PHILLIPS, M. A. Lexical structure of text. Birmingham: University of Birmingham, 1989.

PORCELLO, F. A. C.; DIAS, F. DE B. C. Verdade x mentira: a ameaça das fakenews nas eleições de 2018 no Brasil. Congresso Brasileiro de Ciências da Comunicação (41.: 2018 set. 02-09: Joiville, SC). Anais [recurso eletrônico]. São Paulo: Intercom, 2018. Anais...2018

RODRIGUES, T.; FERREIRA, D. Estratégias digitais dos populismos de esquerda e de direita: Trabalhos em Linguística Aplicada, v. 59, n. 2, p. 1070-1086, 20 maio 2020. 


\section{REVISTA DA ABRALIN}

SILVA, R. O. Um mapa da «direita» no YouTube do Brasil através dos métodos digitais. Dissertação de mestrado em Ciências da Comunicação - Cultura Contemporânea e Novas Tecnologias-Lisboa: Universidade Nova de Lisboa, 2018.

SIYANOVA-CHANTURIA, A.; MARTINEZ, R. The Idiom Principle Revisited. Applied Linguistics, p. amt054, 2014. STUBBS, M. British Traditions in Text Analysis: Firth, Halliday and Sinclair. In: Text and corpus analysis. London: Blackwell, 1996. p. 23-50.

SWINNEY, D. A.; CUTLER, A. The access and processing of idiomatic expressions. Journal of Verbal Learning and Verbal Behavior, v. 18, n. 5, p. 523-534, out. 1979.

TABOADA, M.; GRIEVE, J. Analyzing appraisal automatically. Proceedings of the AAAI Spring Symposium. Anais... In: AAAI SPRING SYMPOSIUM ON EXPLORING ATTITUDE AND AFFECT IN TEXT: THEORIES AND APPLICATIONS. 2004

THOMPSON, G. Introducing functional grammar. London: Arnold, 1996.

VAN LEEUWEN, T. Introducing social semiotics. London; New York: Routledge, 2005.

VARIS, P. Trump tweets the truth: Trabalhos em Linguística Aplicada, v. 59, n. 1, p. 428-443, 24 abr. 2020.

VISCARDI, J. M. Fake news, verdade e mentira sob a ótica de Jair Bolsonaro no Twitter. Trabalhos em Linguística Aplicada, v. 59, n. 2, p. 1134-1157, 21 maio 2020.

WARD, J. H. Hierarchical Grouping to Optimize an Objective Function. Journal of the American Statistical Association, v. 58, n. 301, p. 236-244, mar. 1963.

WILLIAMS, G. Collocational Networks: Interlocking Patterns of Lexis in a Corpusof Plant Biology Research Articles. International Journal of Corpus Linguistics, v. 3, n. 1, p. 151-171, 1998. 